\author{
Alternative Questions in Turkish* \\ Martina Gračanin-Yüksek \\ Middle East Technical University, Faculty of Education, Department of Foreign Language \\ Education, 06800 Çankaya/Ankara \\ mgy@alum.mit.edu
}

(Received 29 April 2015; accepted 16 June 2016)

\begin{abstract}
The paper examines alternative questions in Turkish from the perspective of the size of the disjoint constituents. At the moment, there exists no consensus in the literature on the topic as to whether alternative questions involve clausal disjunction accompanied by a deletion operation in one or both of the disjuncts or they contain no phantom structure, i.e. are disjunctions of phrases no bigger than they appear on the surface. Both of these views have been proposed over the years: a big-disjunct analysis has been advocated by Gračanin-Yüksek (2016), Han and Romero (2004a, 2004b), and Roelofsen and Pruitt (2011) among others, while Beck and Kim (2006), Erlewine (2014), and Larson (1985) among others have defended the small-disjunct analysis. In this paper, looking at possible word order patterns of alternative questions in Turkish, I show that properties of alternative questions in this language cannot be explained on the small-disjunct analysis. I present evidence that underlyingly, alternative questions in Turkish involve clausal disjuncts. Next, by examining the distribution of the question particle in alternative questions and comparing it to the distribution of the same particle in polar questions, I propose that the disjuncts in Turkish alternative questions are full CPs.
\end{abstract}

Keywords: alternative questions, Turkish, disjunction, deletion, (forward) gapping, polar questions, interrogative particle $m I$.

* I am grateful to the editor and two anonymous Dilbilim Araştırmaları Dergisi reviewers for their insightful contributions to the final version of the paper. I am also thankful to audiences of WAFL 10 and ICTL 17 for their helpful questions and comments. Finally, a big thanks to all my Turkish informants for their native speaker judgments: Mehmet Akkuş, Ufuk Ataş, Gözde Balıkçı, Orhan Demir, Betil Eröz-Tuğa, Fatma Gümüşok, Cendel Karaman, Hale Işık-Güler, Çiğdem Sağın-Şimşek, Perihan Savaş, Gülden Taner, Özlem Türe Abac1, and the students registered in the Introduction to Syntax course in the Fall 2013. I am solely responsible for all the remaining errors. This research is supported by Bilimsel Araştırma Projeleri BAP-08-11-2014-011.

http://dx.doi.org/10.18492/dad.98860

Dilbilim Araştırmaları Dergisi, 2016/1, 39-68.

(C) 2016 Boğaziçi Üniversitesi Yayınevi, İstanbul. 


\section{Türkçede Seçenekli Sorular}

ÖZ: Bu çalışmada Türkçedeki seçenekli sorular, ayırma öbeklerinin büyüklüğü açısından ele alınmaktadır. Seçenekli soruların çözümlemeleri hakkında literatürde kesin bir ortak görüş yoktur. Bir görüşe göre bu yapılardaki ayırma öbekleri tümce düzeyinde silme işlemi sonucu oluşmuştur, dolayısıyla bu yapılar tümce düzeyinde ayırma yapılarıdır, diğer bir görüşe göre ise bu yapılardaki ayırma öbekleri yüzeyde göründügünden daha büyük hayalet öbekler içermemektedir. Bu iki görüş de literatürde savunulmuştur. Büyük ayırma öbeği görüşü Gračanin-Yüksek (2016), Han ve Romero (2004a, 2004b), ve Roelofsen ve Pruitt (2011) tarafindan savunulurken, Beck ve Kim (2006), Erlewine (2014), ve Larson (1985) ve diğerleri küçük ayırma öbeği çözümlemesini desteklemektedir. Bu çalışmada Türkçe seçenekli sorulardaki farklı sözcük dizimlerine bakarak, Türkçedeki seçenekli soruların küçük öbek çözümlemesiyle açıklanamayacağını ve bu yapıların tümce düzeyinde ayırma içerdiğini göstereceğiz. Ayrıca, soru parçacığının seçenekli sorularda dağılımını kutuplu sorulardaki dağılımıyla kıyaslayarak, Türkçe'deki seçenekli sorulardaki ayırma öbeklerinin Tümleyici Öbekleri olduğunu savunacağız.

Anahtar sözcükler: seçenekli sorular, Türkçe, ayırma, silme, (öne doğru) boşaltma, kutuplu sorular, soru parçacı̆̆ı $m I$.

\section{Introduction}

In languages like English, questions that contain a disjunction of constituents, illustrated in (1), are ambiguous between a yes/no reading, paraphrased in (2a), and an alternative reading, paraphrased in $(2 \mathrm{~b})$.

(1) Does John drink coffee or tea?

(2) a. Yes/no reading:

Is it the case (or isn't it) that John drinks either of the two: \{coffee, tea\}?

b. Alternative reading:

Which of the two \{coffee, tea\} does John drink?

Such questions have received quite a bit of attention in the literature, both from the syntactic and the semantic point of view. Various scholars have shown that the two readings of (1) behave differently under various manipulations introduced into the structure (Beck and Kim, 2006; Han and Romero, 2004a, 2004b; Larson, 1985, among others). For example, there are environments, attested cross-linguistically, in which the alternative reading disappears, but the 
yes/no reading survives. ${ }^{1}$ Thus, the alternative reading is lost if the question contains a high negation, a focus operator above the disjunction, or if the disjunction is embedded in a syntactic island. ${ }^{2}$ The three environments are illustrated in (3a-c) respectively.

(3) a. Doesn't John drink coffee or tea?

$\checkmark$ Yes/no / $\times$ Alt

b. Does only John drink coffee or tea?

$\checkmark$ Yes/no / $\times$ Alt

c. Do you believe [the claim [that Bill resigned or retired]]? $\checkmark$ Yes/no / $\times$ Alt

In recent years, various proposals have been put forth about the structure of alternative readings that attempt to capture both the fact that questions like (1) have this reading and the fact that it is absent from examples in (3). Crosslinguistically, the proposals vary most prominently with respect to how big they propose the disjuncts in an alternative question to be. ${ }^{3}$

According to the proposed size of the disjuncts, two different analyses of alternative questions (AQs) ${ }^{4}$ have been proposed: the small disjunct analysis (Beck and Kim, 2006; Erlewine, 2014; Larson 1985) and the big disjunct analysis (Gračanin-Yüksek, 2016; Han and Romero, 2004a, 2004b; Roelofsen and Pruitt, 2011). According to the small-disjunct analysis, the disjuncts in an

1 See also Gračanin-Yüksek (2016) for environments in Croatian where the alternative reading survives, but the yes/no reading becomes unavailable.

2 Larson (1985) argues that the ungrammaticality of (3c) is explained if an AQ contains a question operator, which originates at the level of disjunction and raises to the beginning of the sentence to mark the scope that the disjunction takes. Beck and Kim (2006), however, note that the alternative reading survives under adjunct island, as in (i):

i. Are you more pleased [when you see Anne or Lena]?

3 Proposals also differ in whether they consider alternative questions to be a subset of $w h$-questions, i.e. in whether or not they propose that an alternative question contains a null $w h$-operator that originates at the edge of the disjunction phrase and subsequently moves to the left periphery, marking the scope of the disjunction (in embedded alternative questions, the $w h$-operator may be not null if it is lexicalized as whether). In this paper, I investigate alternative questions in Turkish from the point of view of the size of the disjuncts, remaining agnostic for now about the presence/absence of the whoperator. Therefore, I refrain here from the discussion of how proposed analyses differ with respect to whether they do or do not posit the $w h$-operator. The interested reader is referred to Han and Romero (2004a, 2004b) and Larson (1985) for arguments in favor of the $w h$-operator and to Beck and Kim (2006) for arguments against such an operator.

4 In the rest of the paper, I use the term alternative question to refer to a question that contains a disjunction and has an alternative reading (possibly in addition to a yes/no reading). 
AQ contain no phantom structure, i.e. they are underlyingly the size that can be observed on the surface. On this analysis, the AQ in (1) has the structure in (4).

(4) Does John drink [[coffee] or [tea $]]$ ?

Small disjuncts analysis

On the big-disjunct analysis, on the other hand, the underlying structure of the disjuncts is bigger than on the surface and the string is derived by deleting (a) part(s) of one of the disjuncts (in languages like English, parts of the second disjunct are deleted). Some implementations of this analysis propose an underlying disjunction of TPs, as shown in (5a) (Han and Romero, 2004a, 2004b), while some propose a disjunction of CPs, as in (5b) (Pruitt and Roelofsen, 2013; Roelofsen and Pruitt, 2011). ${ }^{5}$
(5) a. Does [[John drink coffee] or [Johndrink tea]]? Big disjuncts analysis (disjunction of TPs)
b.[[Does John drink coffee] or [does John drink tea]]?Big disjuncts analysis (disjunction of $\mathrm{CPs}$ )

Finally, Uegaki (2014) proposes a hybrid approach, according to which AQs can in principle contain either small disjuncts or big disjuncts and the choice of how these questions are derived in a particular language depends on the kind of disjunction that the language in question has in its lexical inventory.

The goal of this paper is to examine AQs in Turkish in light of the analyses that have been proposed for the construction cross-linguistically. I will be particularly interested in what Turkish data can tell us about the underlying size of the disjuncts in an AQ.

Turkish differs from English (and similar languages) in two important ways: (i) in Turkish, disjunctive yes/no questions differ in form from disjunctive alternative questions and (ii) Turkish is a scrambling head-final language, so constraints on possible word orders in AQs might be informative about the structure that underlies the construction. We will see that the properties of Turkish AQs cannot be derived by the small disjuncts analysis, and require instead an analysis on which disjuncts are bigger than the surface strings suggests. In fact, we will see evidence which argues that the disjuncts in a Turkish AQ are the size of the CP.

The paper is organized as follows: in section 2, I introduce AQs in Turkish. Section 3 explores possible word orders in matrix AQs, arguing for the big disjunct analysis of AQs. Section 4 examines embedded AQs in light of the conclusions reached based on the investigation of matrix contexts and suggests that possible word orders in embedded AQs are compatible with the big

5 Han and Romero (2004a, 2004b) also consider a disjunction of vPs a possibility. 
disjunct analysis. In Section 5, I turn to the question of exactly how big the disjuncts in an AQ actually are, arguing that they involve full interrogative clauses. Section 6 is the conclusion.

\section{Turkish Alternative Questions}

In Turkish, AQs are formed by inserting after each alternative/disjunct, the particle $m I$, otherwise used as a question particle in polar questions. ${ }^{6}$ The disjuncts are optionally disjoint by the word yoksa 'if not', but the presence of $m I$ after each alternative remains obligatory regardless of whether yoksa is present or absent. ${ }^{7}$ The obligatory presence of $m I$ in each disjunct in an AQ is not surprising since this particle, besides being the lexicalization of the interrogative force of an utterance also serves as a question focus particle (Kornfilt, 1997: 438), i.e. it may mark as focused a particular constituent in a polar question. It seems to be cross-linguistically true that alternatives in an AQ are necessarily focused. In languages like English, this is indicated by the focus

6 The particle $m I$ is classified as a clitic (Kornfilt, 1997) which undergoes vowel harmony with the constituent to its left and "does not receive word final stress, but causes the preceding syllable to be stressed." (Aygen, 2007: 2) However, as stated in Göksel and Kerslake (2005) and Kornfilt (1997), if there are other factors affecting the stress (for example, if $m I$ is preceded by a suffix which resists stress), the stress is determined by internal stress pattern of the word or phrase to which $m I$ attaches.

7 An anonymous reviewer brings to my attention questions like (i), in which both yoksa and the $m I$ 's on the alternatives are absent and the question has both the alternative and the yes/no reading, depending on the intonation.

$$
\begin{array}{ll}
\text { i. Çay, kahve? } & \checkmark \text { Yes/no / } \checkmark \text { Alt } \\
\text { tea coffee } & \\
\text { 'Tea, coffee?' } &
\end{array}
$$

In this paper, I leave aside questions like these since they seem to appear mostly in colloquial Turkish and are characterized by a set of properties that set them apart from "regular" alternative and yes/no questions. For example, the question has the alternative reading only if everything but the alternatives is unpronounced, as shown by the absence of this reading in (ii). Further, (i) resists embedding, as seen in (iii).

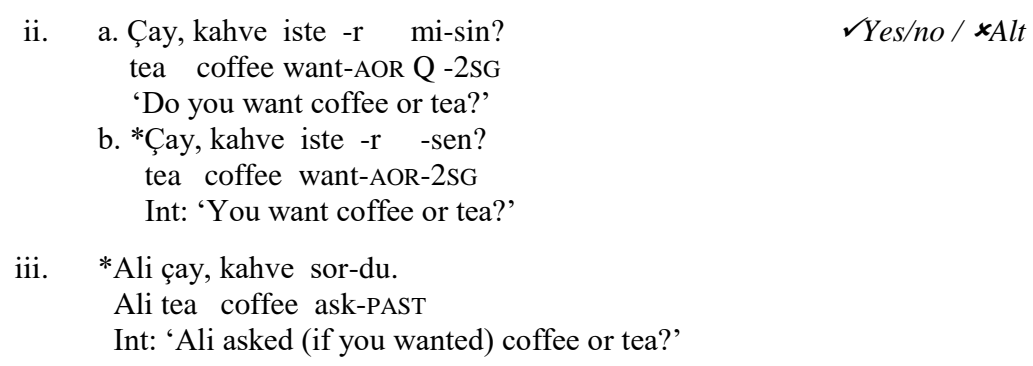


stress that the disjuncts receive (Han and Romero, 2004b; Pruitt, 2008; Pruitt and Roelofsen, 2011; 2013). In Turkish, this seems to be (additionally) indicated by the presence of $m I$. An example of a Turkish polar question is given in (6) below, while the example in (7) illustrates an AQ.

(6) Nermin çay $m \iota$ iç -ti?

Polar question

Nermin tea Q drink-PAST.

'Did Nermin drink tea?'

(7) Ali çay $m \iota$ (yoksa) kahve $m i$ iç -ti?

Alternative question

Ali tea $\mathrm{Q}$ not-if coffee $\mathrm{Q}$ drink-PAST

'Did Ali drink tea or coffee?'

AQs in Turkish may also be embedded, as in (8), regardless of whether the embedded clause is tensed, as in (8a) or not, as in $(8 b){ }^{8}$

(8) a. Hasan [Ali kahve mi (yoksa) çay mı iç -ti ] san -dı?

Hasan [Ali coffee Q not-if tea Q drink-PAST] believe-PAST

'Did Hasan believe that Ali drank COFFEE or TEA?'

b. Hasan [Ali'nin kahve mi (yoksa) çay mı iç -tiğ -in -i ]

Hasan [Ali-GEN coffee Q not-if tea Q drink-N -POSS.3SG-ACC]

sor-du.

ask-PAST

'Hasan asked whether Ali drinks/drank COFFEE or TEA.'

In Turkish, questions like (7) or (8) cannot receive a yes/no reading. Disjunctive yes/no questions do not contain the disjunction yoksa. Instead, the disjunction phrase is headed by either ya da or veya, both meaning 'or.' In

8 In (8a), the AQ is embedded under the matrix predicate san- 'think' and the question takes matrix scope. In (8b), however, it appears under the predicate sor- 'ask', where it has embedded scope. Whether an embedded AQ receives embedded or matrix scope seems to depend on a number of factors, including the lexical semantics of the embedding predicate as well as the means of complementation (Coşkun, 2010). Such variability in scope is not limited to AQs: wh-phrases which occur in an embedded whquestion behave in the same way (sometimes take matrix and sometimes embedded scope), as shown in (ia-b). This suggests that the scope of an embedded interrogative element depends on factors that are independent of the structure of AQs.

i. a. Anne -m para -yı kim çal -mış san-1yor? mother-POSS.1SG money-ACC who stole-PERF believe-PROG 'Who does my mother think stole the money?'

b. Ahmet kitab-1 kim-in al -diğ-in $\quad-1 \quad$ sor-uyor. Ahmet book-ACC who-GEN took-N -POSS.3SG-ACC ask-PROG 'Ahmet is asking who took the book.' 
addition, in a disjunctive yes/no questions, the question particle $m I$ only appears once, as shown in (9).

(9) Ali çay ya da/ veya kahve iç -ti mi? Disjunctive yes/no question Ali tea or $_{1} /$ or $_{2}$ coffee drink-PAST Q

'Did Ali drink tea or coffee (or didn't he)?'

Given that disjunctive yes/no questions and AQs are distinct from one another on the surface, we expect manipulations like those in (3a-c) to affect AQs, but not yes/no questions. Indeed, examples in (10a-b) below show that adding a focus operator above the disjunction does not affect the grammaticality of the yes/no question in (10a), but renders the AQ in (10b) ill-formed. ${ }^{9}$

(10) a. Sadece Ali çay ya da/ veya kahve iç -ti mi? only Ali tea or $_{1} /$ or $_{2}$ coffee drink-PAST Q

'Did only Ali drink tea or coffee?'

b. *Sadece Ali çay $m \iota$ (yoksa) kahve $m i$ iç -ti?

only Ali tea $\mathrm{Q}$ not-if coffee $\mathrm{Q}$ drink-PAST

\#'Did only Ali drink TEA or COFFEE?'

However, Turkish AQs behave differently from their English counterparts when they are embedded inside a syntactic island. As a reviewer points out, a relative clause (RC) in Turkish an island for movement, as shown in (11), but embedding an AQ into it, as in (12), does not result in ungrammaticality.

(11) $* \mathrm{Bu}$ kitab-1 $\mathrm{i}_{\mathrm{i}} \quad$ Cansu $\left[t_{i}\right.$ oku -yan] bir adam-la konuş-uyor. this book-ACC Cansu read-REL one man -with speak -PRES.PROG.

*'This book Cansu is speaking to the man who is reading.'

9 The survival of the alternative reading under a preposed negation cannot be tested in Turkish because the language does not have a possibility of pre-posing negation; negation appears as a suffix on the verb or as a separate word (değil, yok) (Kornfilt, 1997: 123-124). It is worth noting, however, that in Turkish, an AQ can be negated, as shown in (i). In that respect, negated AQs in Turkish resemble those negated AQ in English in which the negation marker in not preposed/contracted, as the translation of (i) indicates. This is in line with Han and Romero's (2004b) claim that only preposed negation causes the disappearance of the alternative reading.

i. Ali çay mı yoksa kahve mi iç -me -di?

Ali tea $\mathrm{Q}$ not-if coffee $\mathrm{Q}$ drink-NEG-PAST

'Did Ali not drink tea or coffee?' 

(12) Ege [Suç ve Ceza'yı mi yoksa Sefiller'i mi Ege Crime and Punishment-ACC Q not-if Les Misérables-ACC Q oku-yan] bir adam-la konuş-uyor? read-REL one man -with speak -PRES.PROG.?
'Is Ege speaking to the man who is reading Crime and Punishment or Les Misérables?'

In light of the ungrammaticality of (11), the well-formedness of (12) may be surprising, but only under the assumption that alternative readings of disjunctive questions necessarily contain a wh-operator that needs to undergo movement to its scope position. ${ }^{10}$ Actually, even on such an analysis, the fact that (12) is grammatical is not entirely mysterious, given the well-formedness of (13), provided by the same reviewer, which shows that the question particle $m I$ may actually scope outside of the RC island even though phrasal movement out of it is impossible.

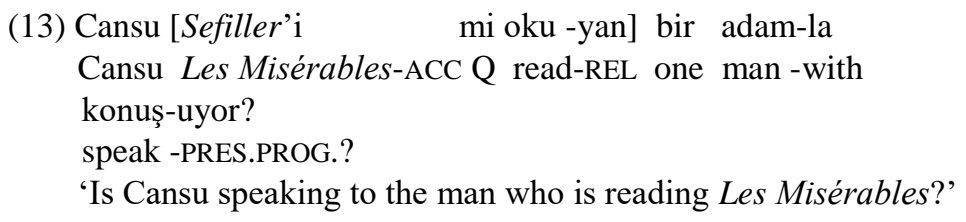

While the cross-linguistic differences in the availability of the alternative reading in a syntactic island are interesting and point to possible differences in the derivation of AQs (and questions in general), I will leave such differences aside for the time being since they are not the main topic of the paper. Rather, in what follows, I will be interested in determining whether disjuncts in a Turkish AQ underlyingly contain more structure than is observable on the surface and if so, how much. We will first see data from Turkish which indicate that the disjuncts in AQs are clausal. The data come from possible word orders in matrix and embedded AQs. Next, by comparing possible placements of the question particle $m I$ in non-disjunctive polar questions with possible placements of this particle in an AQ, I will argue that the disjuncts are in fact full-fledged CPs.

\section{Possible Word Orders in Matrix AQs}

In matrix AQs, the second disjunct (together with yoksa, when present) can appear post-verbally, in an extraposed position. This is shown in (14b), which is an extraposed variant of (14a).

10 See Beck and Kim (2006) for arguments against such an analysis of AQs. 
(14) a. [Ali mi ] [(yoksa) [Ayşe mi]] kahve içti?

Ali Q not-if Ayşe Q coffee drank

'Was it Ali or Ayşe who drank coffee?'

b. [Ali mi ] kahve içti [(yoksa) [Ayşe mi]]?

Ali Q coffee drank not-if Ayşe Q

If the disjuncts in an AQ are small, i.e. not bigger than what they appear on the surface, then (14a) involves a disjunction of DPs (Ali mi, Ayşe mi). On this assumption, the word order in (14b) is derived by a rightward movement of the second disjunct together with the disjunction yoksa over the verb içti 'drank.' This movement is illustrated in (15).

(15) [[ Ali mi] $\left.t_{1}\right]$ kahve içti [(yoksa) Ayşe mi $\left.]\right]_{l}$ ?

If, on the other hand, the disjuncts in an AQ are big (bigger than on the surface), then both (14a) and (14b) are clausal disjunctions, the difference between the two lying in the deleted material. On this assumption, (14a) involves the structure in (16a), with parts of the first disjunct deleted. The extraposed version in (14b) underlyingly looks like (16b), with parts of the second disjunct elided.

(16) a. [[Ali mi kahve içti] [(yoksa) [Ayşe mi kahve içti ]]]? =(14a) Ali Q coffee drank not-if Ayşe Q coffee drank

b. [[Ali mi kahve içti] [(yoksa) [Ayşe mi kahve içti ]]]? =(14b) Ali Q coffee drank not-if Ayşe Q coffee drank

While both of these options (movement, illustrated in (15) and selective deletion, illustrated in (16)) are in principle permitted by universal grammar, independent facts about Turkish grammar argue against the small-disjunct analysis in (15), forcing us to adopt the big-disjunct analysis in (16). In order to see this, we first need to familiarize ourselves with the functions and the distribution of the Turkish question particle $m I$.

\subsection{Question particle $\mathrm{mI}$}

As mentioned in section 2, in Turkish, the interrogative particle $m I$ has a dual function: (i) it turns a statement into a yes/no question (in this usage, $m I$ takes scope over the entire proposition), and (ii) it functions as a question focus particle (Kornfilt, 1997: 438), in which case it narrows down the questioned part of the proposition (in this usage, $m I$ questions only the phrase to which it is attached (Göksel and Kerslake, 2005: 256), i.e. it takes narrow scope). While 
any placement of $m I$ allows for a narrow scope interpretation of a question, only the following placements also yield a wide scope reading:

i. The placement of $m I$ on the predicate (sentence-finally) (Göksel and Kerslake, 2005; Kamali, 2011; Kornfilt, 1997), illustrated in (17a), and

ii. The placement on the immediately pre-verbal constituent (Göksel and Kerslake, 2005; Kamali 2011), illustrated in (17b).

(17) a. Ali araba ald $1 \quad m \imath$ ?

Ali car bought $Q$

Wide scope reading: 'Did Ali buy a car?'

Narrow scope reading: 'Did Ali BUY a car?

b. Ali araba $m \iota$ aldı?

Ali car Q bought

Wide scope reading: 'Did Ali buy a car?'

Narrow scope reading: 'Was it a car that Ali bought?'

If $m I$ appears in a position other than those illustrated in (17), it necessarily functions as a question focus particle, focusing the constituent to which it attaches. With this much in mind, let us return to the discussion of the possible analyses of AQs.

As we saw in (14) above, the second disjunct in a Turkish AQ may appear extraposed, in a position to the right of the verb. This is perhaps not surprising, given that Turkish is a scrambling language and phrases more generally may occupy non-canonical positions in a sentence. Importantly, this is also true of polar questions: in a polar question, neither focused constituents (those immediately followed by the particle $m I$ ) nor non-focused constituents (those not attached by $m I$ ) are tied to only a single position. This is illustrated in (18b), where the non-focused subject scrambled rightward across the verb, and in (19b), where the focused adjunct scrambled to the front of the question.
(18) a. Ali dün çay mı içti?
Ali yesterday tea Q drank
'Did Ali drink tea yesterday?'
b. Dün çay mı içti Ali? yesterday tea Q drank Ali
(19) a. Ayşe yarın mı okula gidecek?
Ayşe tomorrow Q school.DAT go.FUT
'Is it tomorrow that Ayşe will go to school?'
b. Yarın $m \iota$ Ayşe okula gidecek? tomorrow Q Ayşe school.DAT go.FUT


Crucially, however, a focused constituent (focus indicated by the presence of $m I$ ) cannot appear to the right of the verb, as shown by the ill-formedness of $(20) \cdot{ }^{11}$

(20) *Ayşe okula gidecek yarın $m i$ ? Ayşe school.DAT go.FUT tomorrow Q

Intended: 'Is it tomorrow that Ayşe will go to school? / Will Ayşe go to school tomorrow?

The contrast between (19b) and (20) on the one hand, and that between (18b) and (20) on the other, argues that scrambling of focused phrases to the right of the verb is prohibited in Turkish (Erguvanl1, 1984; Göksel, 1998; Göksel and Özsoy, 2000; Kural, 1992).

Recall, however, that in the extraposed AQ in (14b), repeated here as (21), the second disjunct, attached by $m I$, appears to the right of the verb.

(21) [Ali mi ] kahve içti [(yoksa) [Ayşe mi]]?

Ali Q coffee drank not-if Ayşe Q

'Was it Ali or Ayşe who drank coffee?'

On the small-disjunct analysis, the only way to derive the word order in (21) from the underlying (14a), repeated here as (22a), is by moving the second disjunct (together with yoksa) rightwards, across the verb, as shown in (15), repeated below as (22b). However, since the moving constituent is focused (as indicated by the presence of $m I$ ), this movement is not licit. Given that the AQ is nevertheless grammatical, we must conclude that the part of the string to the right of the verb did not move there. Consequently, the small-disjunct analysis cannot be correct for Turkish AQ.

(22) a. [Ali mi ] [(yoksa) [Ayşe mi]] kahve içti?

Ali Q not-if Ayşe Q coffee drank

'Was it Ali or Ayşe who drank coffee?'

b.[[ Ali mi] $\left.t_{l}\right]$ kahve içti [(yoksa) Ayşe mil] $]_{l}$ ?

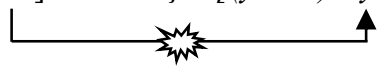

11 Recall that the particle $m I$ when placed on any constituent other than the predicate and the immediately preverbal constituent necessarily functions as a focus particle, i.e. focuses the phrase to which it attaches. Thus, the adverbial phrase yarn $m l$ 'tomorrow?', because it is focused, cannot scramble to a position after the verb. 
This leaves us with the analysis in (16), repeated as (23), on which the disjuncts in an AQ are bigger than on the surface, i.e. involve deletion of material in one of the disjuncts.

(23) a. [[Ali mi kahve içti] [(yoksa) [Ayşe mi kahve içti ]]]? =(16a) Ali Q coffee drank not-if Ayșe Q coffee drank

b. [[Ali mi kahve içti] [(yoksa) [Ayşe mi kahve içti ]]]? Ali Q coffee drank not-if Ayşe Q eoffee drank

The analysis in (23) straightforwardly explains why extraposed AQs in Turkish are well-formed despite the fact that focused material appears post-verbally this is because the structure is bi-clausal, so no movement of focused material across the verb obtains.

In the next section, we will see that the proposed analysis also explains possible word orders in sentences that contain an embedded AQ.

\section{Possible Word Orders in Embedded AQs}

As we have seen in (8) above, AQs can be embedded, but in contrast to matrix AQs, in embedded AQs, the second disjunct (with yoksa, when present) originating in an embedded AQ, can appear neither (immediately) to the right of the embedded verb, as shown by (24b), nor (immediately) to the right of the matrix verb, as (24c) shows. ${ }^{12}$

12 The reported judgments are based on a survey of twenty-five native speakers of Turkish, who were asked to evaluate sentences in (24) both as statements and as questions. They were instructed to assign the sentence any intonation they needed in order to get a well-formed statement/question (a native Turkish speaker was asked to pronounce for the informants each sentence both as a statement and as a question). As to (24a), twenty-two informants found it well-formed on a statement interpretation, while all twenty-five found it ill-formed as a question. All twenty-five speakers found example (24b) ill-formed both as a statement and as a question. Finally, twenty-two speakers could not interpret (24c) as a statement. By contrast, twenty speakers found this example to be good on a matrix questions reading, paraphrased in (i).

i. Did Ege ask whether Ali drank coffee or did Ege ask whether Ali drank tea?

Recall from (8b) and footnote 8 that an AQ embedded under the matrix predicate sor'ask' yields narrow scope interpretation for the question. Thus, it is unlikely that the well-formedness of (24c) on the reading in (i) is a result of the interrogative embedded particle(s) taking scope at the matrix level. Rather, the availability of the reading in (i) is best explained by positing a different syntactic structure for that reading. I return to this issue in section 4.1 . 
(24) a. Ege Ali'-nin süt mü (yoksa) çay $m \iota$ iç -tiğ-in -i Ege Ali -GEN milk Q not-if tea Q drink-N -POSS.3SG-ACC sor-du.

ask-PAST

'Ege asked whether Ali drinks MILK or TEA.'

b. *Ege Ali'-nin süt mü iç -tiğ-in -i (yoksa) çay $m \imath$ Ege Ali-GEN milk Q drink-N -POSS.3SG-ACC not-if tea Q sor-du. ask-PAST

c. *Ege Ali'-nin süt mü iç -tiğ-in -i sor-du (yoksa) Ege Ali -GEN milk Q drink-N -POSS.3SG-ACC ask-PAST not-if çay $m \imath$.

tea $\mathrm{Q}$

The small-disjunct analysis offers a straightforward explanation of these facts: if the examples in (24b-c) involve small disjuncts, then they also involve rightward movement of a focused phrase over the (embedded/matrix) verb, which explains the ill-formedness of the examples. However, we have seen above that extraposed variants of matrix AQs argue against small disjuncts and suggest that AQs are clausal disjunctions instead. Since it is highly unlikely that the same construction (i.e., an AQ) involves different structures depending on whether it is embedded or not, we are well advised to seek an alternative explanation for the facts in (24).

To this end, let us take a closer look at the underlying structure of examples in (24) on the big-disjunct analysis and at the deletion operations that would have to be posited in order to derive examples (24a-c) from such a structure. On this analysis, the grammatical AQ in (24a), as well as the two ungrammatical ones in (24b-c) arise from different deletion operations that apply to (25).

(25) [Ege [[Ali'-nin süt mü iç -tiğ-in -i]

Ege Ali -GEN milk Q drink-N -POSS.3SG-ACC

[yoksa [Ali'-nin çay $\mathrm{m} ı$ iç -tiğ-in $\quad$-i]]] sor-du.]

not-if Ali-GEN tea Q drink-N -POSS.3SG-ACC ask-PAST

The well formed example in (24a) is derived by the ellipsis illustrated in (26).

(26) [Ege [[Ali'-nin süt mü iç tiğ - in $-i]$

Ege Ali-GEN milk Q drink-N -POSS.3SG-ACC

[yoksa [Ali' nin çay $\mathrm{m}$ iç -tiğ-in -i]]] sor-du.]

not-if Ali -GEN tea Q drink-N -POSS.3SG-ACC ask-PAST 
The fact that $(24 \mathrm{c})$ is ill-formed also follows straightforwardly from this analysis, since no deletion operation can derive the string in $(24 \mathrm{c})$ from the underlying structure in (25). Finally, in order for the (ungrammatical) word order in (24b) to arise, the derivation would have to include the deletion operation in (27).

(27) [Ege [[Ali'-nin süt mü iç -tiğ-in -i]

Ege Ali-GEN milk Q drink-N -POSS.3SG-ACC

[yoksa [Ali' nin çay $\mathrm{mi}$ iç, tiğ in in i]]] sor-du.]

not-if Ali -GEN tea Q drink-N -POSS.3SG-ACC ask-PAST

The difference between (26), which derives the grammatical (24a), and (27), which, if allowed, would derive the ungrammatical (24b) is only in the direction of the deletion operation that elides the verb: in (26), it applies backwards, while in (27), it applies forward. If we want to maintain the claim that both matrix and embedded AQs in Turkish involve big disjuncts, we should find a way to exclude the deletion operation in (27), without excluding the one in (26).

In fact, there exists evidence that the ellipsis in (27) is disallowed in Turkish, while the ellipsis in (26) is allowed. The argument is based on the fact that the operation in (27), but not the one in (26), can be reduced to forward gapping and forward gapping in Turkish has been argued to be a root phenomenon, i.e. to apply only to matrix clauses (İnce, 2009a). In the following subsection, I review the arguments for this claim.

\subsection{Forward gapping in Turkish}

İnce (2009a, 2009b) shows that examples like (28), which involve forward gapping in the embedded clause, are ungrammatical.

(28) *Zeynep [Hasan'-in karides-i ye-diğ-in $\quad$-i ]

Zeynep Hasan -GEN shrimp-ACC eat-N -POSS.3SG-ACC

[Mehmet'-in de istiridye-yi ] duy-du.

Mehmet-GEN and oyster -ACC hear-PAST

'Zeynep heard that Hasan ate shrimp and Mehmet the oyster.' 13

13 An anonymous reviewer brings to my attention Göksel (2011), where it is argued that the (perceived) ill-formedness of examples like (28) stems from the fact that the embedded fragment Mehmet'in de istiridyeyi is located in the Focus Field of the matrix clause and as such receives stress, garden-pathing speakers into parsing this fragment as an argument of the matrix verb, which is impossible, and thus results in the rejection of the sentence. Göksel puts forth (i) below, arguing that removing the embedded fragment 
The example improves if the rightmost conjunct extraposes to a position after the matrix verb, as in (29) (Kornfilt, 2000).

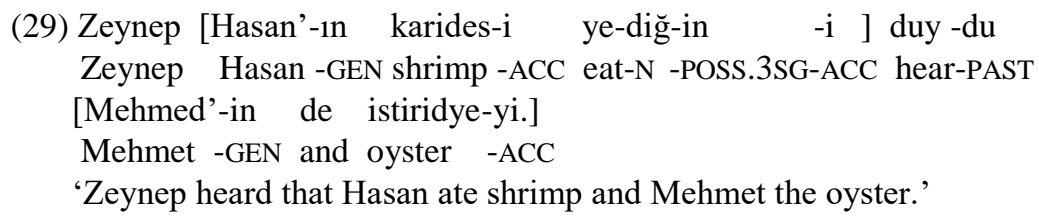

Kornfilt (2000) proposes that the contrast between (28) and (29) is due to "a condition in Turkish syntax that precludes the generation of embedded clauses that are not verb-final and which are internal to a higher clause." Since in (28), the embedded clause is internal to the superordinate clause, the sentence is out. In (29), on the other hand, the embedded clause is not internal to the matrix clause (is not followed by any material belonging to the higher clause) and the sentence is grammatical.

If Kornfilt is correct, the ungrammaticality of (24b) is expected, but it is puzzling that the AQ in $(24 c)$ is ill-formed, given that in $(24 c)$, the embedded disjunct has been extraposed to a position where it is not followed by matrix material. The relevant examples are repeated below for convenience.

from the Focus Field, thus "rescuing" it from receiving stress, improves the sentence and renders it well-formed:

i. Zeynep [Hasan'-1n karides-i ye-diğ-in -i ] Göksel (2011:67) Zeynep Hasan -GEN shrimp-ACC eat-N -POSS.3SG-ACC

[Mehmet'-in de istiridye-yi ] ÇOKTAN bil -iyor-du. Mehmet-GEN and oyster -ACC for.some.time know-PROG-PAST 'Zeynep has known for some time now that Hasan ate shrimp and Mehmet the oyster.'

As a follow-up to the reviewer's comments, I polled six more native speakers of Turkish asking them to judge sentences like (i). All six agreed that (i) is slightly better than (28), but all said that the sentence is still severely degraded. Similarly, when asked to judge (ii) below on the statement reading, my informants judged it as not quite as bad as (24b), but still not acceptable.

ii. ??Ege Ali'-nin süt mü iç -tĭğ-i $\quad$-ni (yoksa) çay mı dün Ege Ali -GEN milk $Q$ drink-N -POSS.3SG-ACC not-if tea $Q$ yesterday akşam sor-du. evening ask-PAST

These judgments support İnce's (2009a) claim that forward gapping is disallowed in Turkish embedded clauses, which I therefore adopt in the text. I, however, agree with the reviewer that the role of prosody in the matter should not be ignored. 
(30) a. *Ege Ali'-nin süt mü iç -tiğ-in -i (yoksa) çay mı Ege Ali-GEN milk Q drink-N -POSS.3SG-ACC not-if tea Q sor-du.

ask-PAST

b. *Ege Ali'-nin süt mü iç -tiğ-in -i sor-du (yoksa) Ege Ali -GEN milk Q drink-N -POSS.3SG-ACC ask-PAST not-if çay $m ı$.

tea $\mathrm{Q}$

İnce (2009a) argues against Kornfilt's claim, discussing examples like (31a), parallel to (29), which involve gapping within a disjunction phrase in the embedded clause. Ince states that (31a) only allows for the reading in (31b), but not for the one in (31c). In other words, by uttering (31a), the speaker does not assert Ahmet's knowledge of the disjunction, but the "disjunction of Ahmet's knowledge."

(31) a. Ahmet Hasan'-1n pasta-yı ye-diğ-in -i bil -iyor, Ahmet Hasan -GEN cake -ACC eat-N -POSS.3SG-ACC know-PRES.PROG. veya Meral'-1n dondurma-y1.

or Meral -GEN ice-cream-ACC

b. 'Either Ahmet knows that Hasan ate pasta or Ahmet knows that Meral ate ice-cream.'

c. \#'Ahmet knows either that Hasan ate pasta or that Meral ate ice-cream.'

The fact that (31a) only has the reading in (31b) suggests that the structure does not involve a disjunction of embedded clauses, but rather involves a disjunction at the matrix level, as shown in (32).

(32) [[Ahmet [Hasan'-1n pasta-yı ye -diğ-in $\quad$-i $\quad$ bil - -iyor] $]$ Ahmet Hasan -GEN cake -ACC eat-N -POSS.3SG-ACC know-PRES.PROG. veya [Ahmet [Meral'-1n dondurma-y1 ye-diğ-in -i or Ahmet Meral-GEN ice-cream-ACC eat-N -POSS.3SG-ACC bil iyor.]]]

knOw-PRES.PROG.

If it is correct, Ince argues, that examples like (31) involve matrix disjunction, as their meaning would suggest, then the well-formedness of such examples shows that forward gapping in Turkish can target matrix clauses. If we strengthen that claim, the argument continues, and assume that forward gapping in Turkish can target only matrix clauses, we can then derive the contrast between (28) and (29) by appealing to the fact that (29) can be derived by eliding parts of a matrix clause, as shown in (33), but in (28), the deletion in the 
second conjunct would necessarily target only the embedded clause, as (34) illustrates. ${ }^{14}$

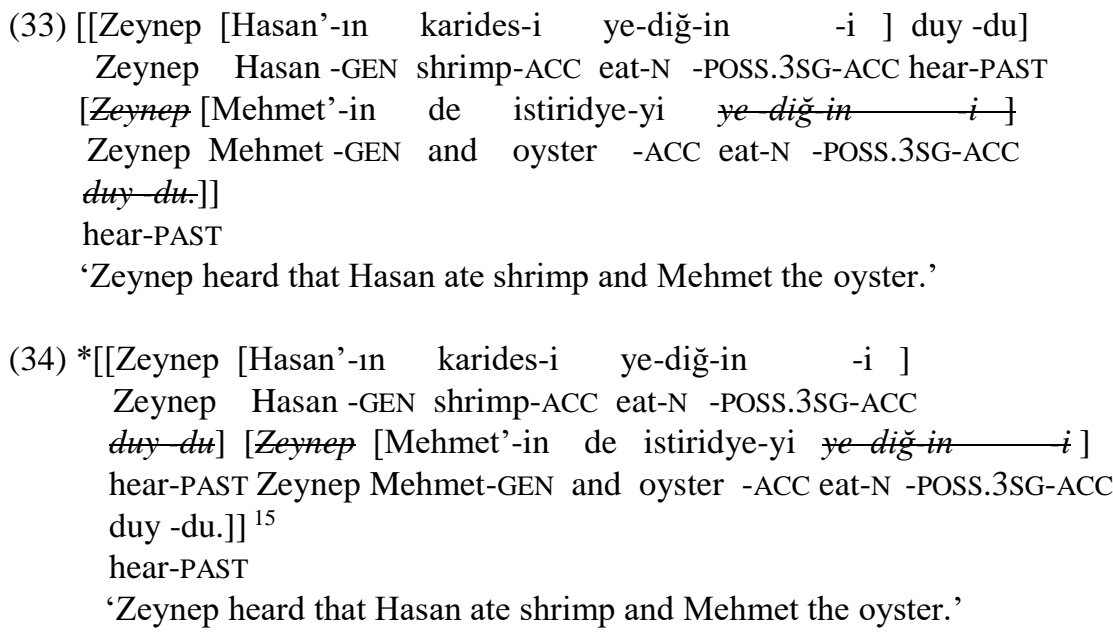

Based on considerations like this, Ince concludes that forward gapping in Turkish is allowed only at the level of the matrix clause. If this argument is successful, then the ill-formedness of our AQ example in (24b) is explained even on the big-disjunct analysis. The example is ill-formed because it involves an illicit instance of forward gapping at the level of the embedded clause, as shown in (27), repeated here as (35). ${ }^{16}$

14 In (33), ellipsis deletes the embedded predicate yediğini in addition to the matrix predicate duydu. This should not be taken as an argument against the claim that the operation can only target the matrix clause. The claim says that as long as (a) part(s) of the matrix clause is elided, ellipsis is allowed. What is not allowed is eliding parts of the embedded clause without affecting the matrix clause.

15 The ungrammaticality of this example could be derived from the coordination of embedded clauses as well. In that case, the first conjunct would underlyingly not contain the matrix verb duydu 'heard' and the second conjunct would not contain the matrix subject Zeynep. However, forward gapping would still affect only the embedded verb in the second conjunct, leading to ill-formendess.

16 The example is predicted to be ungrammatical (for the same reason) even if it underlyingly contains disjunction on the matrix level, as indicated by (i).

i. *[Ege [[Ali'-nin süt mü iç -tiğ-i $\quad$-ni] for dtt] yoksa

Ege Ali-GEN milk Q drink-N -POSs.3sG-ACC ask-PAST not-if

[Ege [Ali' nin çay $\mathrm{m}$ i

Ege Ali -GEN tea Q drink-N -POSs.3SG-ACC ask-PAST 
(35) *[Ege [[Ali'-nin süt mü iç -tiğ-in $-\mathrm{i} \quad]$

Ege Ali -GEN milk Q drink-N -POSS.3SG-ACC

[yoksa [Ali'-nin çay $\mathrm{m}$ iç tiğ-in $-i \quad$ ]] sor-du.]

not-if Ali -GEN tea Q drink-N -POSS.3SG-ACC ask-PAST

Recall that the grammatical AQ in (24a) differs from the ungrammatical (24c) only in the direction of the gapping: while in (24c) it applies forward, in (24a), repeated here as (36), it applies backwards. ${ }^{17}$

(36) [Ege [[Ali’-nin süt mü $i c ̧ \quad t i \check{g}$-in $-i \quad$ ]

Ege Ali-GEN milk Q drink-N -POSS.3SG-ACC

[yoksa [Ali' nin çay mı iç -tiğ-in $\quad$-i l] ] sor-du.]

not-if Ali -GEN tea Q drink-N -POSS.3SG-ACC ask-PAST

This difference proves to be crucial since backward gapping, unlike forward gapping, is not a root phenomenon in Turkish. To illustrate this fact, Ince (2009b) offers the contrast below between (37) - an example of forward gapping of the embedded verb - and (38) - an example of backward gapping of the embedded verb. ${ }^{18}$

(37) *Ali Ege'-nin çikolata -yı ye -diğ-in -i

Ali Ege -GEN chocolate-ACC eat-N -POSS.3SG-ACC

Mehmet'-in (de) armud-u biliyor.

Mehmet-GEN also pear -ACC knows

Intended: 'Ali knows that Ege ate chocolate and Mehmet the pear.'

(38) Ali Ege'nin çikolata -y1 Mehmet'-in (de)

Ali Ege -GEN chocolate-ACC Mehmet -GEN also

armud-u ye-diğ-in $-\mathrm{i}$ biliyor.

pear -ACC eat-N -POSS.3SG-ACC knows

'Ali knows that Ege ate chocolate and Mehmet the pear.'

17 Again, (24a)/(36) is predicted to be well-formed even if it contains disjoint matrix clauses, as in (i). In (i), gapping not only applies backwards, but also targets the matrix clause, yielding a grammatical result.

i. *[Ege [[Ali'-nin süt mü tiğ in -i] sor du] yoksa

Ege Ali -GEN milk Q drink-N -POSs.3sG-ACC ask-PAST not-if

[Ege [Ali'-nin çay $\mathrm{m}$ iç -tiğ-in $\quad$-i $]]$ sor-du.]

Ege Ali -GEN tea Q drink-N -POSS.3SG-ACC ask-PAST

18 To derive the contrast, İnce (2009b), following Hankamer (1971), proposes that instances of backwards gapping in Turkish should be analyzed as instances of Right Node Raising, rather than gapping proper. 
Finally, in (36) and in comparable examples, the forward-applying deletion of the embedded genitive subject in the second disjunct (Ali'nin) is allowed because this operation is not gapping: gapping is defined in Bozşahin (2000) as 'identical verb deletion under coordination'; it refers to the deletion operation that necessarily targets verbal material (Coppock, 2001). Thus, while nothing in Turkish grammar prevents the generation of (24a), restrictions on forward gapping exclude (24b).

The fact that in Turkish, forward gapping, while being prohibited in embedded clauses, freely applies to matrix clauses also explains the fact that (24c) is well-formed on a matrix question reading. Thus, (39), with the reading paraphrased in footnote 12 , is fully grammatical.

(39) Ege Ali'-nin süt mü iç -tiğ-in $\quad$-i $\quad$ sor-du (yoksa)

Ege Ali -GEN milk Q drink-N -POSS.3SG-ACC ask-PAST not-if

çay $m \imath$ ?

tea $\mathrm{Q}$

'Did Ege ask whether Ali drank milk, or did Ege ask whether Ali drank tea?'

This reading arises from the disjunction of two interrogative clauses, as shown in (40). Deriving the string in (39) from the matrix disjunction in (40) also requires forward gapping. However, this time, the targeted clause is the matrix clause, which accounts for the well-formedness of the example, as well as for its matrix question reading. ${ }^{19}$
(40) [[Ege [Ali'-nin süt mü iç -tiğ -in $\quad$-i ] sor-du ]
Ege Ali-GEN milk Q drink-N -POSS.3SG-ACC ask-PAST
[yoksa [Ege [Ali'-nin çay mı iç tiğ-in $\quad-i \quad$ sor-du? ]]]
not-if Ege Ali-GEN tea Q drink-N -POSS.3SG-ACC ask-PAST

So far, we have seen that the small-disjunct analysis cannot explain possible word orders found in Turkish AQs; while such an analysis is plausible for embedded AQs, it cannot explain the fact that in matrix AQs the second disjunct may appear post-verbally. By contrast, an analysis that posits big disjuncts, coupled with the restrictions on forward gapping in Turkish, can explain word order possibilities in both matrix and embedded AQs.

19 Forward gapping also applies in matrix AQ where the second disjunct appears in the postverbal position. However, since the deletion applies at the matrix level, such examples are well-formed. 
Now that we know that disjoint constituents in an AQ are underlyingly bigger than on the surface, our next task is to determine exactly how big these constituents are. This is the topic of the next section.

\section{The Structure of the Disjuncts}

As mentioned in the Introduction, there exist various proposals about the actual size of the unpronounced structure found in AQ-disjuncts: some researchers propose that the disjoint constituents are vPs or TPs (Han and Romero, 2004a; 2004b), while some propose that they are CPs (Pruitt and Roelofsen, 2013; Roelofsen and Pruitt, 2011; Uegaki 2014). In this section, I will address the question of whether AQs in Turkish contain disjoined CPs, or they are disjunctions of smaller sized constituents. To this end, I will consider the distribution of the question particle $m I$ in AQs. The discussion will lead to the conclusion that AQs in this language involve a disjunction of full-fledged interrogative clauses.

The (overt portion of the) disjuncts in AQs may cross-linguistically be of various sizes: DP, VP, TP, or even $\mathrm{CP}$, as illustrated in (41a-d) by examples from English.

(41) a. Did [DP John] or [DP Sally] leave the party early?

b. Did John [vp drink wine] or [vp smoke pot]?

c. Did [те John drink wine] or [тр Sally smoke pot]?

d. [CP Did John drink wine] or [CP did Sally smoke pot]?

Recall from section 2 that alternatives in an AQ are necessarily focused (Han and Romero, 2004b; Pruitt, 2008; Pruitt and Roelofsen, 2013; Roelofsen and Pruitt 2011). However, it is not necessary that the entire disjunct string be focused. It is possible that, in each disjunct, the constituent that is focused (i.e. the alternative) comprise a subpart of the string of the disjunct. An example is given in (42). In (42), only the DPs wine and juice are focused (indicated by small caps), although each disjunct contains more material than that.

(42) Did Sally bring WINE or did she bring JUICE? (Roelofsen and Pruitt, 2011)

It is, however, also possible that the entire string of at least one disjunct be focused, as in (43a-b). In (43a), the second disjunct is overtly realized as a single DP, tea, which bears focus. The focused DP in the first disjunct is coffee, the DP contrasting with tea. In (43b), the alternatives are entire CPs; the question is asking whether it is true that Bob sold the car or it is true that Jane took a loan. Consequently, in (43b), both disjuncts seem to be focused in their entirety. 
(43) a. Did John drink COFFEE or TEA?

b. DID BOB SELL THE CAR or DID JANE TAKE A LOAN?

As mentioned in section 3.1, $\mathrm{mI}$ in Turkish functions as an interrogative particle (when it takes scope over the entire proposition) and as a question focus particle (when it scopes only over the immediate constituent to which it is attached). In a polar question, all legitimate placements of $m I$ potentially yield a narrow-scope (focused) reading of the question. ${ }^{20}$ However, $m I$ can only take scope over the entire proposition (wide scope) when it is sentence-final, as in (44a) (Göksel and Kerslake, 2005; Kornfilt 1997), or when it occupies an immediately preverbal position, as in (44b) (Göksel and Kerslake, 2005; Kamali, 2011).

(44) a. Ali araba ald $\quad m \imath$ ?

Ali car bought $\mathrm{Q}$

Wide scope reading: 'Did Ali buy a car?'

Narrow scope reading: 'Did Ali BUY a car?

b. Ali araba $m \iota$ aldı?

Ali car Q bought

Wide scope reading: 'Did Ali buy a car?'

Narrow scope reading: 'Was it a car that Ali bought?'

Following Aygen (2007) and Kornfilt (1997), I assume that $m I$ takes wide scope when, at LF, it has the entire proposition in its c-command domain, i.e. when it occupies the $\mathrm{C}^{0}$ position. This presumably obtains in narrow syntax when $m I$ is sentence final and via some sort of covert head movement when $m I$ is immediately preverbal. If this is correct, we can formulate the following prediction about the size of the disjuncts in a Turkish AQ: if an AQ that overtly contains clausal disjuncts which contrast with one another (à la (43b)) can also contain sentence-final $m I$ 's, we have evidence that the disjuncts in an AQ are CPs. If, on the contrary, $m I$ cannot occupy a sentence final position even when the alternatives in the AQ are entire (contrasting) propositions, then disjuncts must be smaller than the $\mathrm{CP}$, the size of the TP or vP.

What we find is the following: In Turkish AQs with clausal disjuncts, $m I$ may occupy the immediately preverbal position in both disjuncts, as (45a)

20 There are a handful of positions that $m I$ can occupy neither in a polar question nor in an AQ: it cannot appear on a pre-nominal DP-internal constituent (with the exception of possessors) and it cannot appear on the complement of a post-position. When these constituents receive a narrow focus interpretation, $m I$ appears on the noun and the postposition respectively. 
shows. Given the interpretation of the example, the immediately preverbal $m I$ here takes wide scope in both disjuncts.

(45) Ahmet araba-y1 $m l$ sat-tı (yoksa) Hasan kredi $m i$ al-d1?

Ahmet car -ACC Q sell-PAST not-if Hasan loan Q take-PAST

'Did Ahmet sell the car or (did) Hasan take a loan?'

When it comes to the availability of sentence-final $m I$, however, the situation is a bit more complicated: $m I$ may appear in the sentence-final position in the first disjunct, but not in the second disjunct. This is shown by the examples in $(46) .^{21}$

(46) a. *Ahmet araba-yı sat-tı $m l$ (yoksa) Hasan kredi al-dı $m l$ ? Ahmet car -ACC sell-PAST Q not-if Hasan loan take-PAST Q Intended: 'Did Ahmet sell the car or (did) Hasan take a loan?'

b. *Ahmet araba-yı $m \imath$ sat-tı (yoksa) Hasan kredi al -dı $m \iota$ ? Ahmet car -ACC Q sell-PAST not-if Hasan loan take-PAST Q Intended: 'Did Ahmet sell the car or (did) Hasan take a loan?'

c. Ahmet araba-yı sat-tı $m l$ (yoksa) Hasan kredi $m i$ al $-\mathrm{d}_{1}$ ? Ahmet car -ACC sell-PAST Q not-if Hasan loan Q take-PAST 'Did Ahmet sell the car or (did) Hasan take a loan?'

Especially interesting for our purposes is the well-formed example (46c). Here, the sentence-final $m I$ in the first disjunct (together with the interpretation of the $\mathrm{AQ}$ ) indicates that this disjunct contains the $\mathrm{C}^{0}$ position, occupied by $\mathrm{mI}$. In other words, the first disjunct seems to be a CP. By the Law of the Coordination of Likes (Williams, 1981), according to which only constituents of the same syntactic make-up may be conjoined, the second disjunct must also

21 An anonymous reviewer states that, in contrasts to (46a), (i) below is grammatical although the disjuncts are clausal and $m I$ occupies a final position in both.

i. Ahmet araba-y1 sat -t1 mi yoksa Hasan kredi al -abil-di mi(ydi)? Ahmet car -ACC sell-PAST Q not-if Hasan loan take-PSB-PAST Q (PAST)

This judgment suggests that the possibility of a final placement of $m I$ in the second disjunct of an $\mathrm{AQ}$ is, at least to a degree, dependent on the tense/aspect/modality marking on the verb. Note, however, that the grammaticality of (i) provides direct support for my claim that disjuncts in a Turkish AQs are CPs (on the assumption that $m I$ in such examples occupies $\mathrm{C}^{0}$ position in narrow syntax). In the remainder of the paper, I develop an argument from prosody to the effect that even those examples that are illformed with $m I$ in the final position in the second disjunct can be reconciled with this claim. 
be a CP. If this conclusion is on the right track, a question arises as to why then this CP cannot host the question particle $m I$ sentence-finally. This question is all the more interesting given that in AQs where disjuncts are overtly the size of VPs, $m I$ can freely appear in a final position (on the verb) in both disjuncts, as shown by (47).

(47) Mehmet [at -a bindi mi] yoksa [at -tan indi mi $]$ ? Mehmet horse-DAT got.on $\mathrm{Q}$ not-if horse-ABL got.off $\mathrm{Q}$ 'Did Mehmet get on the horse or off the horse?'

Note, however, that in (47) the disjuncts are not entire propositions contrasting with one another. Instead, the disjunct-final $m I$ focuses only the verb (or possibly the VP) in each disjunct, and it is the verbs/VPs that contrast with one another, rather than full clauses. So, it is plausible to assume that in (47), $m I$ in each disjunct does not occupy $\mathrm{C}^{0}$, but rather some other position, from where it scopes only over the verb/VP, but not over the subject. The contrast between the ungrammatical (46a-b) and the grammatical (47) then lies in the structural position of $m I$ : it seems to be the case that in an AQ, although $m I$ can appear disjunct-finally, in the second disjunct, it (paradoxically) cannot occupy (its otherwise canonical) $\mathrm{C}^{0}$ position.

I believe that the reason for the ill-formedness of (46a-b) lies in the prosody of Turkish interrogatives. Here is why: When both disjuncts in an AQ are full CPs that contrast with one another, each of those two CPs (i.e. both disjuncts) must be pronounced with the prosody characteristic of a wide-scope polar question. At the same time, however, an AQ per se is associated with a specific kind of a prosodic contour, which results from the fact that the two alternatives are contrasted with one another. I would like to propose that these two prosodic demands imposed by an AQ containing contrasting clausal disjuncts may both be met in the first disjunct, but only one may be satisfied in the second disjunct when it contains a final $m I$. This conflict leads to the fact that such utterances are ill-formed. With this much in mind, let us take a closer look at the prosody of yes/no and alternative questions in Turkish.

\subsection{Prosody of Turkish polar and alternative questions}

Turkish polar questions that involve $m I$ in the sentence-final position are pronounced with a high rise in the intonation just before $m I$, followed by falling intonation (Göksel and Kerslake, 2005; Kawaguchi, Y1lmaz, and Y1lmaz, 2006). Kornfilt (1997) states that in a polar question with $m I$ on the predicate, as in (48), the stress falls on the predicate, followed by a drop in the pitch immediately after the intonation peak. This is illustrated in (48). 
(48)

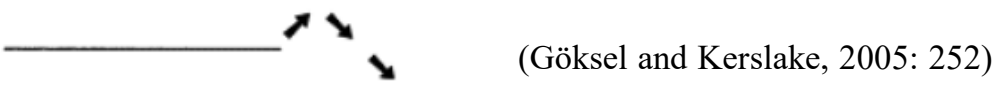

Saatini ileri al-DIN mı?

'Have you put your watch forward?'

The intonation pattern in (48) is characteristic not only of wide scope polar questions, but also of polar questions in which the verb is narrowly focused, as in the underlined part of (49).

(49) Ali'-nin araba-yı kirala-yacağ-ın $\quad-1 \quad$ san $\quad-d_{1} \quad-m$. Ali-GEN car -ACC rent -FUT -POSS.3SG-ACC think-PAST-1SG 'I thought Ali was going to rent the car.'

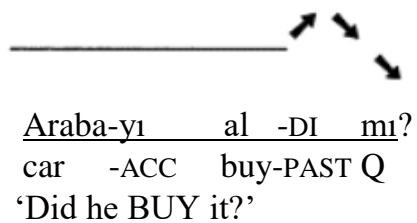

As to AQs, Göksel and Kerslake (2005) state that in an AQ, "each alternative has a high rise followed by a fall, sometimes with a rise in the juncture point between the two alternatives" (pg. 254), as in (50).

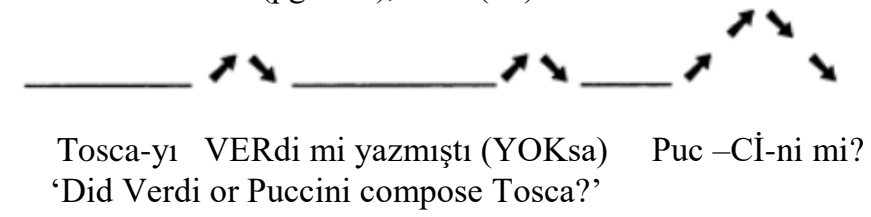

According to this description, the two disjuncts in an AQ are produced with similar prosodic contours, the difference lying in the degree of the rising in the picth, rather than in the general pattern. This indeed may be the correct pattern for the AQs like that in (50), in which subjects are focused. I will, however, take Göksel and Kerslake's illustration of the pitch contour of the AQ in (50) to mean that this prosodic parallelism between the two disjuncts holds of all AQ, regardless of the constituent that is focused. ${ }^{22}$ My informants, however, produce AQs with $m I$ in the final position in each disjunct (like the one in (47))

22 This may be unwarranted, but I will take it as my starting point since Göksel and Kerslake's (2005) text does not contain illustrations of different AQs and their prose suggests a certain degree of generality over different types of AQs. The reader should, however, keep in mind that this generalization is not explicitly stated by the authors. 
with quite a different intonation: in such an AQ, the two disjuncts are pronounced very differently from one another, as shown in (51b) below ((51b) is the representation of the pitch contour of the AQ in (47), repeated here as (51a)). The first disjunct is pronounced with a pitch that rises just before $m I$ (and continues to rise on $m I$ itself). By contrast, in the second disjunct, the region right before $m I$ is pronounced with a falling pitch contour, which continues to fall on $m I$.

(51) a. Mehmet [at -a bindi $m i$ yoksa $\left[\begin{array}{llll}\text { at } & \text {-tan indi mi }\end{array}\right.$ ?

Mehmet horse-DAT got.on $\mathrm{Q}$ not-if horse-ABL got.off $\mathrm{Q}$

'Did Mehmet get on the horse or off the horse?'

b.

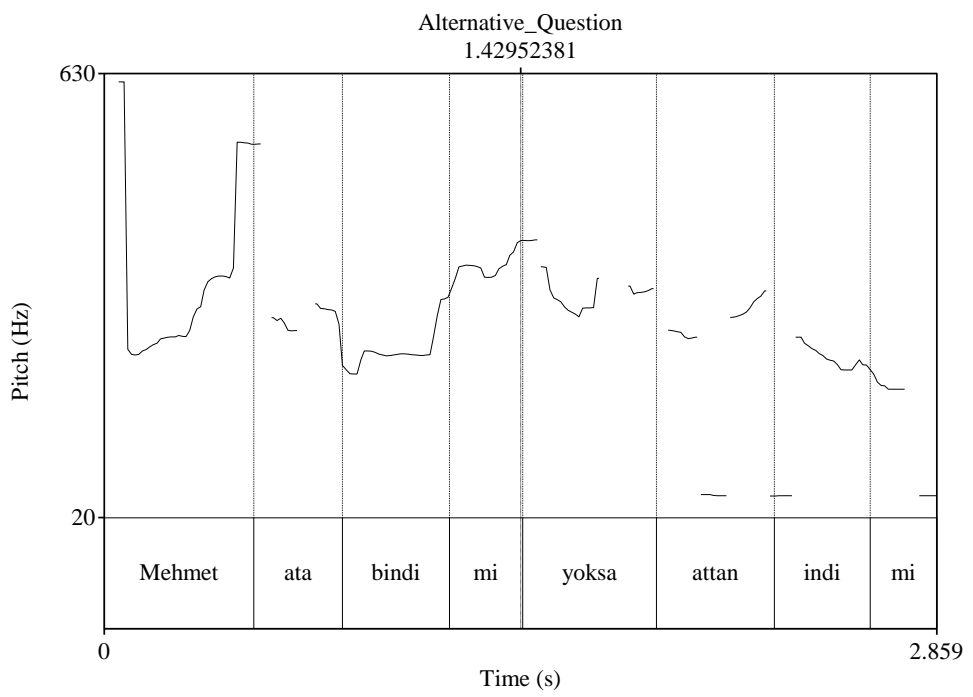

The intonation of the first disjunct is similar to the intonation of a simple yes/no question, shown in (52b), in that in both cases there is a rise in the pitch before $m I .^{23}$

(52) a. Mehmet at -tan indi mi?

Mehmet horse-ABL got.off Q

'Did Mehmet get off the horse?'

\footnotetext{
${ }^{23}$ The two intonation contours are not identical, however. While in a polar question, the pitch drops steeply on $m I$ itself, in the first disjunct of an AQ, the pitch on $m I$ continues to rise.
} 
b.

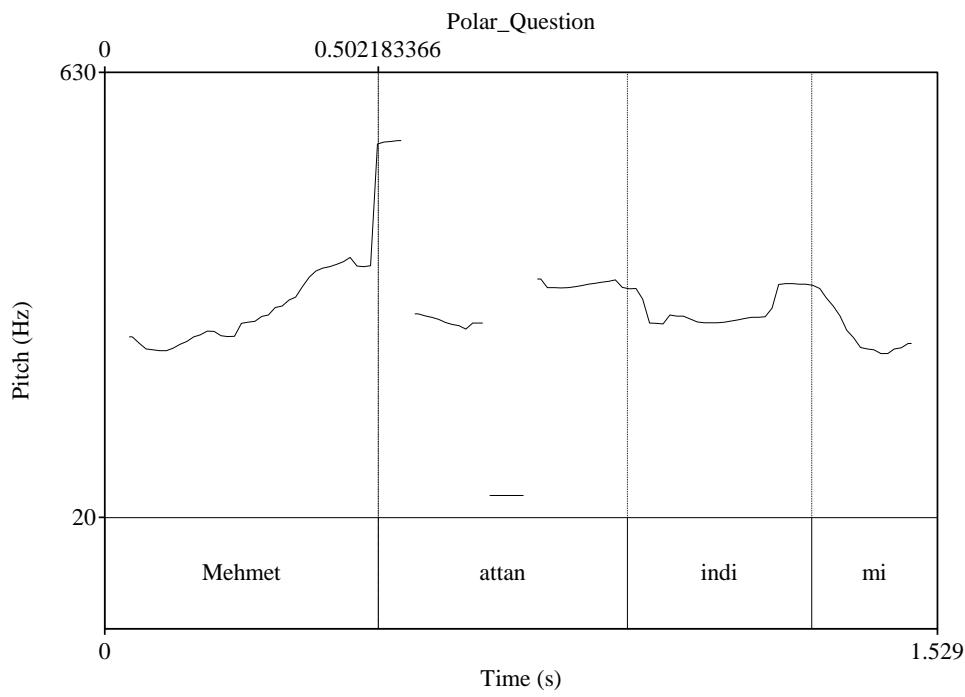

The second disjunct, however, seems to have very different prosodic properties. In (53) below, I provide the pitch contour of the VP in the second disjunct of the AQ in (47) and the pitch contour of the VP in the polar question in (52a). Although both VPs comprize the identical string of words (attan indi mi?), the VP in the second disjunct in an AQ (53a) features a fall in pitch right before $m I$, while the VP in a polar question (53b) features a rise in the same region.

(53) a. Pitch contour of the VP in the $2^{\text {nd }}$ disjunct of the AQ in (47)

AQ-VP_in_the_second_disjunct

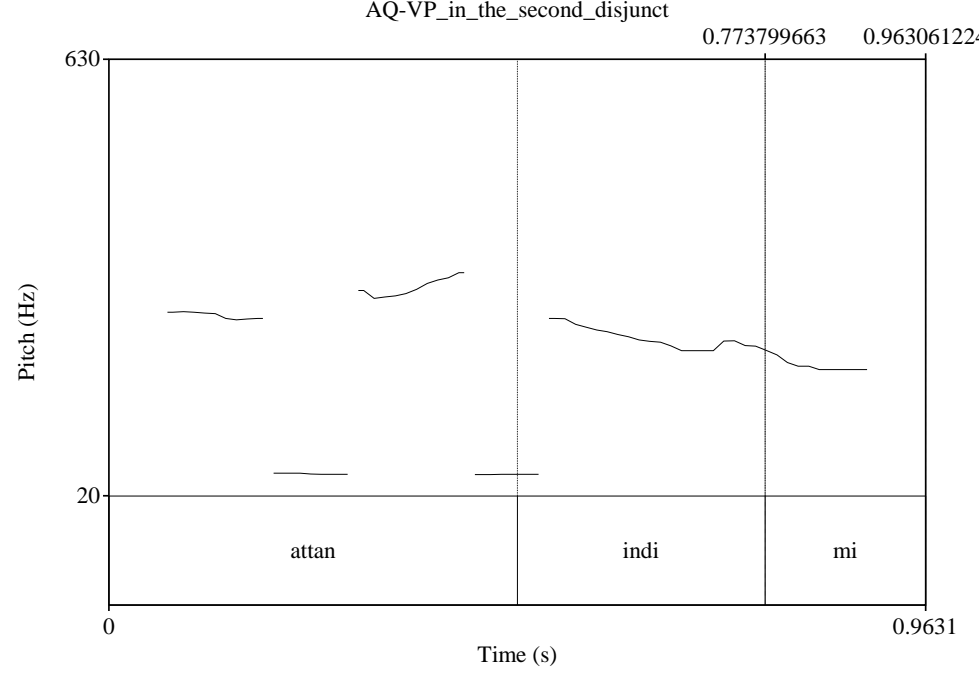


b. Pitch contour of the VP in the polar question in (52a)

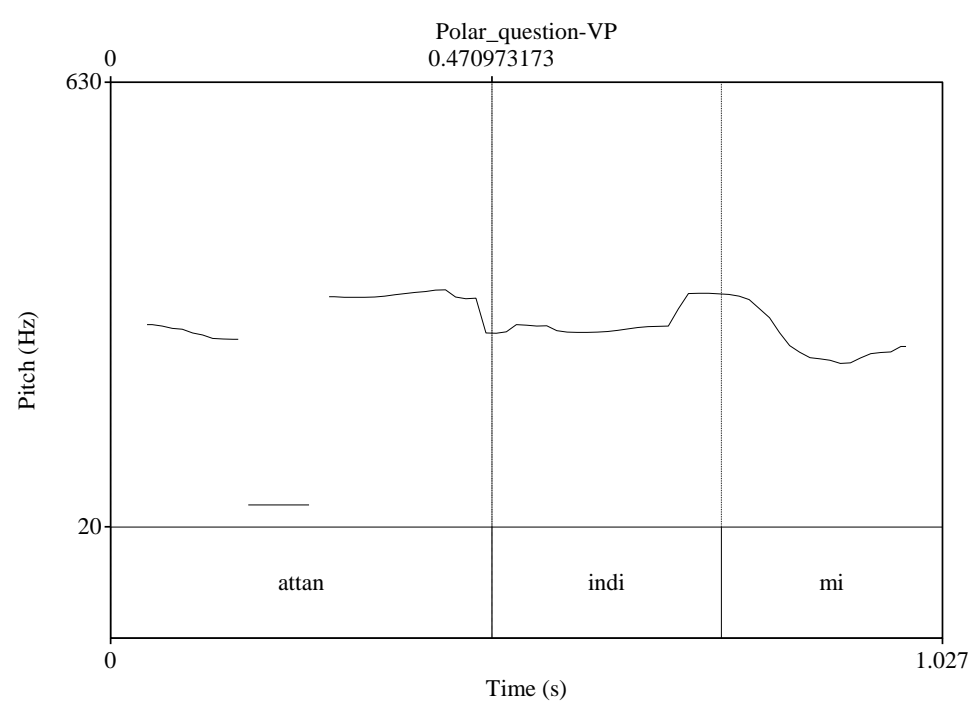

Given that the intonation which accompanies the constituent preceding $m I$ in the second disjunct of an AQ features an obligatory fall in the pitch contour, but the polar question with a wide scope reading and a final $m I$ requires the obligatory rise in the pitch on that same constituent, it is not surprising that the second disjunct in an AQ cannot be clausal and at the same time contain a final $m I$. It is the impossibility of realizing both of these obligatory intonation requirements that makes (46a-b) ungrammatical, rather than the syntactic make-up of the disjuncts.

\section{Conclusion}

In this paper I took up the question of what AQs in Turkish, a scrambling headfinal language, can tell us about the structure of AQs in general. In particular, I was interested in how Turkish AQs can inform the debate on the structure of these questions cross-linguistically. We have seen that Turkish data, both from matrix and embedded AQs, lend support to the analysis of AQs which posits big disjuncts coupled with the deletion in one or both of the disjuncts. Matrix AQs were shown to be incompatible with small-disjunct analysis because on such an analysis extraposed versions of matrix AQs would have to involve a rightward movement of a focused constituent across the verb, which is otherwise disallowed in the language. The attested word orders in embedded AQs, although in principle derivable on the small-disjunct analysis, were also shown to be compatible with the big-disjunct analysis, necessary for explaining 
the matrix facts. We saw that possible and impossible word orders in embedded AQs can be accounted for once the fact is taken into consideration that forward gapping in Turkish is a root phenomenon, and cannot apply in embedded contexts (İnce, 2009a; 2009b). I thus conclude that the observed properties of AQs in Turkish argue in favor of the big-disjunct analysis of AQs (GračaninYüksek, 2016; Han and Romero, 2004a, 2004b; Roelofsen and Pruitt, 2011), and against the analysis that posits surface-size disjuncts (Beck and Kim, 2006; Erlewine, 2014; Larson 1985).

I was also interested in discovering what the syntactic make-up of the disjuncts is in an AQ. The fact that AQs in Turkish can contain contrasting clauses and that the question particle $m I$ may occupy the clause-final position in the first disjunct indicates that the disjuncts are underlyingly CPs. The fact that $m I$ cannot appear clause-finally in the second disjunct, which might be taken as counter-evidence to this claim, was argued to be the consequence of prosodic rather than syntactic properties of the disjoint constituents. More precisely, I argued that $m I$ cannot occupy the $\mathrm{C}^{0}$ position in the second disjunct in an AQ because this disjunct must be pronounced with a falling pitch right before $m I$, but the wide scope reading of the disjunct requires a rise in pitch in this position.

\section{References}

Aygen, G. (2007). Q-particle. Dil ve edebiyat dergisi, 4 (1), 1-30.

Beck, S. and Kim, Sh. (2006). Intervention Effects in Alternative Questions. Journal of Comparative German Linguistics, 9, 165-208.

Bozşahin, C. (2000). Gapping and word order in Turkish. In A. Sumru Özsoy, Didar Akar, Mine Nakipoğlu-Demiralp, Eser E. Erguvanl1-Taylan, and Ayhan Aksu-Koç (Eds.), Studies in Turkish Linguistics: Proceedings of ICTL 10 (pp. 95-104). Istanbul: Boğaziçi University Press.

Coppock, E. (2001). Gapping: in defense of deletion. In M. Andronis, C. Ball, H. Elston, and S. Neuvel (Eds.), Proceedings of the Chicago Linguistic Society 37 (pp. 133148). University of Chicago.

Coşkun, H. (2010). Question elements in Turkish complement clauses. Turkic Languages, 14, 43-68.

Erguvanli, E. (1984). The Function of Word Order in Turkish Grammar. Berkeley: University of California Press.

Erlewine, M. Y. (2014). Alternative questions through focus alternatives in Mandarin Chinese. In A. Beltrama, T. Chatzikonstantinou, J. L. Lee, M. Pham, and D. Rak (Eds.), Proceedings of the 48th Meeting of the Chicago Linguistic Society (pp. 221234). University of Chicago.

Göksel, A. (1998). Linearity, focus and the postverbal position in Turkish. In L. Johanson (Ed.), The Mainz Meeting Proceedings of the Seventh International Conference on Turkish Linguistics (pp. 85-106). Wiesbaden: Harrassowitz Verlag. 
Göksel, A. (2011). A phono-syntactic template for Turkish: Base-generating free word order. In A. Nolda and O. Teuber (Eds.), Syntax and Morphology Multidimensional, Interface Explorations (pp. 45-76). Mouton de Gruyter.

Göksel, A. and Kerslake, C. (2005). Turkish: A Comprehensive Grammar. London: Routledge.

Göksel, A. and Özsoy, S. (2000). Is there a focus position in Turkish? In A. Göksel and C. Kerslake (Eds.), Studies on Turkish and Turkic Languages; Proceedings of the Ninth International Conference on Turkish Linguistics (pp. 219-228). Wiesbaden: Harrassowitz Verlag.

Görgülü, E. (2006). Variable wh-words in Turkish. Unpublished MA thesis, Boğaziçi University, Istanbul.

Gračanin-Yüksek, M. (2016). Size Matters: The Syntax of Disjunctive Questions. Linguistic Inquiry, 47 (2), 283-305.

Han, C-H. and Romero, M. (2004a). The Syntax of Whether/Q...Or Questions: Ellipsis Combined with Movement. Natural Language and Linguistic Theory, 22 (3), 527564.

Han, C-H. and Romero, M. (2004b). Disjunction, Focus, and Scope. Linguistic Inquiry, 35 (2), 179-217.

Hankamer, J. (1971). Constraints on Deletion in Syntax. Unpublished doctoral dissertation, Yale University, New Haven, CT.

İnce, A. (2009a). Gapping in Turkish. In A. Schardl, M. Walkow, and M. Abdurrahman (Eds.), Proceedings of thirty-eighth annual meeting of the North East Linguistic Society (pp. 425-438). Amherst: GLSA.

İnce, Atakan (2009b). On right node raising. In R. Shibagaki and R. Vermeulen (Eds.), Proceedings of Workshop on Altaic Formal Linguistics 5 (pp. 165-180). MIT Working Papers in Linguistics 58.

Kamali, B. (2011). The Question Particle in Turkish: Consequences for the Interfaces. In M. Byram Washburn, S. Ouwayda, Ch. Ouyang, B. Yin, C. Ipek, L. Marston, and A. Walker (Eds), Online complement to Proceedings of WCCFL 28. Last retrieved on April 24, 2015, from https://sites.google.com/site/wccfl28pro/kamali.

Kawaguchi, Y., Y1lmaz, S., and Y1lmaz, U. (2006). Intonation Patterns of Turkish Interrogatives. In Y. Kawaguchi, I. Fónagy, and T. Moriguchi (Eds.), Prosody and Syntax: Cross-linguistic Perspectives (pp. 349-368). Amsterdam/Philadelphia: John Benjamins Publishing Company.

Kornfilt, J. (1997). Turkish. London/New York: Routledge.

Kornfilt, K. (2000). Directionality of identical verb deletion in Turkish Coordination. In S. Chung, J. McCloskey, and N. Sanders (Eds.), Jorge Hankamer WebFest. Last retrieved on April 24, 2015 from http://ling.ucsc.edu/Jorge/kornfilt.html.

Kural, M. (1992). Properties of Scrambling in Turkish. Unpublished manuscript, UCLA.

Larson, R. (1985). On the syntax of disjunction scope. Natural Language and Linguistic Theory, 3, 217-264.

Pruitt, K. and Roelofsen, F. (2013). The interpretation of prosody in disjunctive questions. Linguistic Inquiry, 44, 632-650.

Roelofsen, F. and Pruitt, K. (2011). Disjunctive questions: Prosody, syntax, and semantics. Paper presented at a seminar at the Georg August Universität Göttingen, April 2011 
Uegaki, Wataru. (2014). Cross-linguistic variation in the derivation of alternative questions: Japanese and beyond. In U. Sauerland and L. Crnič (Eds.), The Art and Craft of Semantics: A Festschrift for Irene Heim (pp. 251-274). Cambridge, MA: MIT Working Papers in Linguistics.

Williams, E. (1981). Transformationless grammar. Linguistic Inquiry, 12, 645-653. 